\title{
CORRIGENDUM
}

\section{Direct observation of single-charge-detection capability of nanowire field-effect transistors}

\author{
J. Salfi, I. G. Savelyev, M. Blumin, S. V. Nair and H. E. Ruda
}

Nature Nanotechnology 5, 737-741 (2010); published online: 19 September 2010; corrected after print: 6 December 2010.

In the version of this Letter originally published, a label in Figure 1a was incorrect. There were also two minor text errors. These errors have now been corrected in the HTML and PDF versions of the text. 